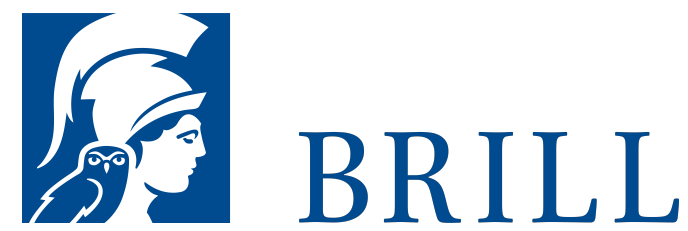

\title{
Der Ost-Experte
}

Gustav Hilger - Diplomat im Zeitalter der Extreme

Author: Jörn Happel

»Deutsche Staatschefs und deutsche Botschafter in Moskau kamen und gingen - aber Gustav Hilger blieb.« - Mit diesen Worten umschrieb Stalin jenen Mann, dessen Biografie im Mittelpunkt von Jörn Happels Studie steht. Als Experte, Diplomat und Dolmetscher war der gebürtige Moskauer von 1918 bis 1941 aus den deutsch-sowjetischen Beziehungen nicht wegzudenken. Er beriet zahlreiche Politiker und Wirtschaftsvertreter und übersetzte für Stalin und Molotov, Hitler und Ribbentrop. Ab 1941 arbeitete Hilger in Berlin als OstExperte gegen die Sowjetunion; diese Tätigkeit setzte er nach dem Krieg für die USA fort. Ab 1953 erklärte er im bundesdeutschen Auswärtigen Amt die Politik in Osteuropa. Folgt man der Perspektive Hilgers, kann die Position der Sowjetunion im 20. Jahrhundert in einer deutsch-sowjetischamerikanischen Verflechtungsgeschichte neu bestimmt werden. Seine Biografie eröffnet unerwartete Perspektiven auf die internationale Politik des 2o. Jahrhunderts.

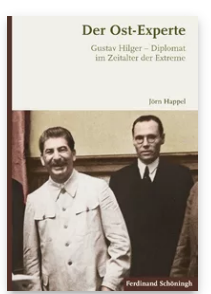

Pages: 533

Seiten, $30 \mathrm{~s} / \mathrm{w}$ Abb.

Language:

German

Subjects:

Modern History,

History

Publisher: Brill |

Schöningh

E-Book (PDF)

Released online:

18 Dec 2017

ISBN: 978-3-

657-786o9-1

List price

Hardback

Publication date: 15 Dec 2017

ISBN: 978-35०6-786o9-8

List price 
Jörn Happel ist Privatdozent für Neuere Allgemeine und Osteuropäische Geschichte an der Universität Basel. Von 2005 bis 2017 war er dort wissenschaftlicher Assistent am Lehrstuhl für Osteuropäische Geschichte.

For more information see brill.com

\begin{abstract}
Order information: Order online at brill.com +44330 3330049 | customerservices@brill.com Submission information: brill.com/authors
\end{abstract}

Titles published by Brill | Fink, Brill | mentis or Brill | Schöningh: +49(o)71 5413279216 | brill@brocom.de 